discussion on unavailable carbohydrates in cereals, fruit and vegetables. Dr D. A. T. Southgate's data from the Dunn Nutritional Laboratory, Cambridge, showed a wide range of polysaccharides with different hexose:pentose ratios in various types of vegetables. Potatoes when cooked in their jackets vary greatly in their lignin content according to the cooking technique.

In the afternoon $\mathrm{Mr} \mathrm{A}$. K. Adatia (University of Bristol) traced the history and geography of dental and periodontal disease and related them to fibre-depleted foods. High sugar intake promotes bacterial fermentation with formation of acids that subsequently erode the dental enamel. White flour binds the sugar and acids to the teeth. The health of gums and teeth, promoted by mastication of fibrous foods, deteriorates with adoption of soft refined food. He suggested that unprocessed foods contain protective factors which enter the enamel of the teeth during its compression and relaxation on mastica. tion. When sucrose is present in the food it enters the teeth in the same way and encourages the development of cavities beneath the enamel.

Dr Trowell supplied evidence that fibre-depleted diets may play a significant part in coronary heart disease and diabetes. He accepted the evidence relating coronary disease to factors such as fats, smoking and exercise, but suggested that dietary fibre should also be considered.

Dr K. W. Heaton (University of Bristol) outlined the history and geography of cholesterol gall stones which are becoming increasingly prevalent in the Western world. Convincing epidemiological and experimental evidence incriminated refined carbohydrate foods as a causative factor, resulting in increased amounts of bile cholesterol and decreased amounts of bile acids required to keep it in solution.

\section{LOW TEMPERATURE BIOLOGY}

\section{Cryosurgical Techniques}

from a Correspondent

BIOLOGISTS interested in the effects of low temperature on living tissue and surgeons using cryosurgical techniques in clinical practice met in London on October 27 for a symposium on cryosurgery organized by the Society for Low Temperature Biology.

Sir James Fraser (University of Southampton) opened the meeting by reviewing the uses of extremely low temperature in surgery. $\mathrm{He}$ described equipment for its application, outlined the advantages of cryosurgery in certain situations and emphasized the need for more fundamental work on the nature of the cryolesion, so that a useful tool, which has been used empirically and clumsily in the past, could be applied more accurately and discretely.

Basically, cryosurgery depends on destruction of tissue by temperatures below $-15^{\circ} \mathrm{C}$. The probes for application consist of concentric tubes, which allow the tip to be cooled by agents such as liquid nitrogen or by expansion of gases such as nitrous oxide. A probe can be passed, for example, into the urethra while warm, then with the tip positioned within the prostate, the gland can be destroyed by freezing. The extent of tissue destruction will depend on temperature drop and duration of application-in other words with probe properties rather than type of tissue to be destroyed.

Three contributors-Sir James, Dr D. K. Whittaker (Welsh National School of Medicine) and $\mathrm{Dr} \mathrm{H}$. W. Rothenborg (University of Copenhagen
Rigshospitalet)-presented results of experiments designed to investigate mechanisms of damage within the socalled ice-ball formed around the probe. These studies suggest that cells at the periphery of the ice-ball freeze but are not necessarily irreversibly destroyed and it is almost certain that only tissue which is frozen below $-15^{\circ} \mathrm{C}$ for at least 3 minutes is destroyed. It is thought that most damage is caused by the direct effect of freezing, but it is possible that ischaemia resulting from vascular stasis and an immune response to frozen cells may also be involved.

The other contributors were clinicians who described their experiences using cryosurgical techniques in brain, prostate, skin, nerve, neoplastic tissues, mouth and eye surgery. Clearly the techniques have demonstrated their value in each of these specialities. The advantages are that there is no haemorrhage; scar tissue is minimal so that cosmetic results are good; there is

\title{
The Eurth's Crust 3,700 Million Years Ago
}

FOR several years the oldest dated rocks on Earth were members of the predominantly volcanic successions that make up the greenstone belts which are such a striking feature of the Precambrian of southern Africa, Canada and Western Australia. Last year, however, it was reported that quartzo-felspathic rocks of granitic composition from an area in West Greenland are more than 3,700 million years old.

In next Monday's Nature Physical Science (November 27), Moorbath, O'Nions, Pankhurst, Gale and MacGregor describe further work on a large collection of material from the region in West Greenland where reconnaissance had shown the presence of rocks older than any other terrestrial material yet dated. The new data confirm the great antiquity of these granitic gneisses, which are shown to have formed more than 3,700 million years ago. The areas from which these very old rocks have survived have escaped a rather widespread metamorphic event which affected many other regions where Precambrian rocks are exposed at present in the Northern Hemisphere.

It seems quite likely that this metamorphic event, which occurred about 3,000 million years ago, has largely obliterated the earlier history of these regions, which include much of east Greenland, north-west Scotland and parts of the Soviet Union. If a means of penetrating this obscurity can be devised it may emerge that much of the granitic crust is at least as old as that of the west Greenland area. No doubt this question will be cleared up in the next few years, but the importance of the work now reported is that it demonstrates that granitic crust had already formed early in the history of the Earth and that this event took place before many of the greenstone belts evolved. In other words, a picture of the early crust is emerging in which a granitic crust, developed perhaps by a primary differentiation of the planet, evolved in time to form a basement on which numerous piles of volcanic rocks were to accumulate later in the Precambrian.

The work of Moorbath and his colleagues at the University of Oxford is also throwing some light on the isotopic make-up of strontium in the early crust. As Moorbath pointed out recently at the annual meeting of the American Geological Society (Abstracts Volume, 1972 Annual Meeting of the Geological Society of America, 599) it is often assumed that the observed strontium isotope ratios are solely related to the source region of a given igneous rock.

In fact work such as that reported on the west Greenland rocks strongly indicates that the observed ratios reflect the sum of many processes which have affected the rocks, such as the differentiation of melting of mantle material, the partial melting of continental crust, the contamination of magma by country rocks and a variety of wall rock alterations. In the light of Moorbath's warning it may be necessary to be more cautious in the future in interpreting strontium isotope ratios. 